\title{
Freudian Repetition and Restoration in Sylvia Plath's Life, Art, and Death
}

\author{
Phillip Potamites
}

Paul Juinn Bing Tan

Hui-mei Yao

Department of Applied Foreign Languages, National Penghu University, Taiwan e-mail : pashatan@yahoo.com.tw

\section{Doi:10.5901/mjss.2014.v5n3p618}

\section{Abstract}

This paper analyzes Sylvia Plath's obsession with death as manifested in her life and poetry. Through her overt display of this obsession in many of her critically acclaimed poems, she provides a poignant and compelling case study exemplifying Freud's theory of a death drive which both conflicts and combines with more agreeable, pleasure-seeking life instincts. Because of her writing's aesthetic value and historical importance, her compositions can be seen as an outstanding example of Freud's concept of "sublimation": the conversion of antisocial tendencies into positive cultural contributions. However, Plath herself eventually succumbed tragically to the dark forces which haunted her life and poetry. Plath's multiple suicide attempts testify to her real-life compulsion towards death, while her poetry includes both direct references and numerous thinly-veiled metaphors. Notably, the parallels to Freud's theories are more nuanced than simple self-destructive tendencies sublimated into beautiful art. These sublimations also reveal Freud's concept of "overdetermined" multiple meanings and include abundant examples of identity "transference". She furthermore reaffirms the death drive as something trapped in repetition seeking restoration of a prior undisturbed state. Finally, her poetry explicitly expresses the ambivalent feelings due to such sublimated, overdetermined symbols which unite the contrasting and converging forces of the life and death instincts. Thus, this paper argues that Plath's poetry attests to both general and specific aspects of the psychological conflicts postulated by Freud's theories of co-conspiring antithetical instincts.

Keywords: Freud, Plath, Death instincts, Life instincts, Obsession, Sublimation

Death, incomprehensible and inexorable, has long awed and obsessed writers. It simultaneously attracts and repulses our sensibilities. Creative writers who suffer from melancholia or other mental illnesses are particularly drawn to this universal theme as they struggle with their psychological problems. A study by Mark A. Runco attests that "there is a close link between creative writers and suicide attempts" (637). If great writers must be more sensitive than ordinary individuals, then they also must be more susceptible to personal tragedy.

Runco further takes the case of Sylvia Plath as "an example that fits in with existing theories of creativity and suicide" (637). Sylvia Plath deserves detailed examination because of both her fame and fine art. Praised as a "welleducated, disciplined writer who usually avoided the sentimentalities of some female writers" (Wagner 1), Plath wrote prolifically from a young age. Her semi-autobiographical novel The Bell Jar is based on events from her life around the time of her first medically documented suicide attempt at the age of 20. Other attempts included crashing a car, after discovering her husband's infidelity, and she ultimately died from self-induced carbon monoxide poisoning at the age of 30. Many of the poems that she left behind explore the topic of death, referencing her previous attempts and foreshadowing her eminent death.

Though Plath explicitly explored themes of death, explaining the motivations of her suicide remains controversial. The more one reads scholars' views on her death, the more confused one may become because she repeatedly spoke of her personal attraction to death and yet there remain so many possible interpretations of this attraction. This paper will argue that Plath's poetry provides excellent evidence for Freud's theory of the death drive, and that understanding these connections can help explain both the appeal of her poetry and the motivations behind her tragic death. Furthermore, her writing should be understood as an attempt to sublimate and transform her relationship to her own overactive death drive into something positive and pleasurable. While extreme Freudians may understand all art in terms of this sublimation of dark personal forces into positive social contributions, Plath's poetry particularly demands this kind of interpretation 
because of her focus on her own self-destructive tendencies. Readers of her poetry will hopefully attest to its positive effects, though she ultimately succumbed to its darker aspects. Her poetry can provide exquisite examples of possible syntheses of the life and death drives, but regrettably failed to sustain her in her own life.

Freud is primarily remembered for his focus on sexual desires and their possible implications in family relations, but to see those as his primary contributions to psychology is to fall into a superficial pop culture caricature of his thinking. His real contribution to serious modern thought is his attempt to understand displaced representations and their importance for, as well as their origin in, the often conflicted nature of the emotions that many, perhaps all of us, must undergo. He even traced these conflicts back to an ever-present struggle between life and death, and Sylvia Plath's poetry, as well as its popular appeal, attest to the validity of his claims.

While Plath's poetry contains explicit examples of the confounding of family and sexual neuroses that Freud is famous for (e.g. "Daddy"), this paper will focus on specific psychological mechanisms that Freud proposed as negotiating between conflicting instincts. As early as the Interpretation of Dreams in 1899, Freud suggested that symbols were "overdetermined"; that is to say, they should have multiple simultaneous interpretations. Dream symbols frequently arise from specific events of the preceding day, and yet will also superimpose these on more deep-seated, primal issues. For instance, a conflict with one's boss may repeat itself in one's dreams but also encode issues one may have with one's parents. Such multiple meanings of symbols may also arise from what Freud called "transference". Freud originally coined the term transference to refer to the transfer of a patient's conflicted feelings about their parents onto their feelings regarding the psychoanalyst. Later psychologists, such as Susan Anderson, have since generalized the term to any imposition of the feelings of past relationships into new relationships or objects. In this more general sense, others' identities may even be internalized as one's own, or one's own identity may be projected onto external objects. This paper will show how Plath both implicitly and explicitly internalizes and externalizes different objects in attempting to cope with her own conflicted emotions. The conflicted nature of emotions which Freud addressed can be referred to as "ambivalence", that is to say a simultaneous feeling towards a single object of love and hate, of desire and fear, of compassion and contempt. Overdetermination and transference, as well as sublimation, are means by which antithetical forces can be synthesized, while ambivalence may be understood as both cause and result.

While Freud's early work insisted that pathologies arose out of the conflict between personal desires, i.e. the id, and social repression, i.e. the superego, his later work acknowledges a fundamental self-destructive drive. Freud's theory of instincts both contrasts and unites instincts which drive towards life and pleasure and those that drive towards death and destruction, respectively empowering and endangering one's desires and actions. He suggests that every living thing has the tendency to return to death, but this parallels life instincts which also seek restoration of previous situations. Whether we subjectively see actions as constructive or destructive, there is comfort in the restoration of prior states of affairs, even if implying our own annihilation. The fundamental unity of instincts, their shared goal, according to Freud, lies in the drive to repeat, in an ever futile attempt to restore, to return to the past.
In the works of my late years (Beyond the Pleasure Principle [1920], and the Ego and the Id [1923]), I have given free rein to the inclination, which I kept down for so long, to speculation, and I have also contemplated a new solution of the problem of the instincts. I have combined the instincts for self-preservation and for the preservation of the species under the concept of Eros and have contrasted it with an instinct of death or destruction which works in silence. Instinct in general is regarded as a kind of elasticity of living things, an impulsion toward the restoration of a situation which once existed by some external disturbance. This essentially conservative character of instincts is exemplified by the phenomena of the compulsion to repeat. The picture which life presents to us is the result of the concurrent and mutually opposing action of Eros and the death instinct" (Freud 645).

Although he describes these forces as "mutually opposing", he also treats them together as a general "elasticity of living things" whose "conservative character... is exemplified by the phenomena of the compulsion to repeat". Other statements reiterate this opposition, this unity, and describe "life itself" as the balance achieved by the "compromise" of these forces.

On the basis of theoretical considerations, supported by biology, we put forward the hypothesis of a death instinct, the task of which is to lead organic life back into the inanimate state; on the other hand, we supposed that Eros, by bringing about a more and more far-reaching combination of the particles into which living substance is dispersed, aims at complicating life and at the same time, of course, at preserving it. Acting in this way, both the instincts would be conservative in the strictest sense of the word, since both would be endeavouring to re-establish a state of things that was disturbed by the emergence of life. The emergence of life would thus be the cause of the continuation of life and also at the same time of the striving towards death; and life itself would be a conflict and compromise between these 
two trends. The problem of the origin of life would remain a cosmological one; and the problem of the goal and purpose of life would be answered dualistically. (Freud 645)

He even goes so far as to claim that "both kinds of instinct would be active in every particle of living substance" (645). However, if life is the compromise of these forces, then death must be the ultimate triumph of one over the other. And one might further suggest that all art finds a compromise between these forces. In Plath's poetry, as well as her life and death, their "conflict and compromise" is candidly expressed, their restorative unity precisely articulated, and this ultimate triumph unfortunately overwhelming and premature. Her mental sensitivity and external circumstances of her life mutually contributed to this premature triumph of the soul's darker forces, but her art can still shine as the sublimative transformation of these dark forces into something beautiful and life-sustaining.

Plath's "Lady Lazarus" is highly confessional and directly references her prior suicide attempts and describes death less as something permanent than something cyclical requiring repeated effort.

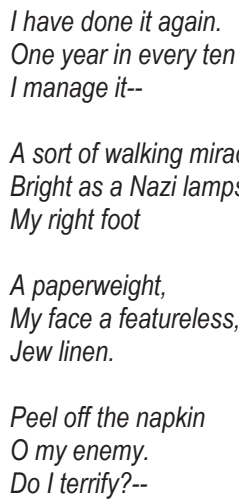

Peel off the napkin

O my enemy.

Do I terrify?--

The nose, the eye pits, the full set of teeth?

The sour breath

Will vanish in a day.

Soon, soon the flesh

The grave cave ate will be

At home on me

And I a smiling woman.

I am only thirty.

And like the cat I have nine times to die.

This is Number Three.

What a trash

To annihilate each decade.

What a million filaments.

The peanut-crunching crowd

Shoves in to see

Them unwrap me hand and foot--

The big strip tease.

Gentlemen, ladies

These are my hands

My knees.

I may be skin and bone,

Nevertheless, I am the same, identical woman.

The first time it happened I was ten. 
It was an accident.

The second time I meant

To last it out and not come back at all.

I rocked shut

As a seashell.

They had to call and call

And pick the worms off me like sticky pearls.

Plath's first medically documented suicide attempt was at the age of 20, and Plath's friend Anne Sexton also refers to Plath's "first suicide" as the basis of The Bell Jar, so this "accident" most likely refers to her father's death, caused by problems from a foot amputation necessitated by his untreated diabetes, when Sylvia was 8. From a Freudian perspective, she can be understood as confessing to the transference of her father's death into her own and identifying his death as an initial locus of trauma which she has "the compulsion to repeat". She demonstrates further identity transference in describing parts of her body as both Nazi and Jew, thus both abuser and victim. Plath may or may not have been susceptible to tinges of racial guilt because her father was German, but she also uses images of German men to personify the forces that she struggled with, as we will see further below.

In alluding to the folk superstition of cats' nine lives, Plath conveys a classic image of repetitive rebirth. Of course, Lazarus was also the friend whom Jesus raised from the dead. However, she insists she intended to "not come back at all". One major challenge of returning from a failed suicide is coping with people's responses, and Plath disparagingly refers to a crowd which "shoves in to see" a "strip tease". The following passage more clearly refers to dying as easy and the "theatrical comeback" as the action that comes with "a very large charge".

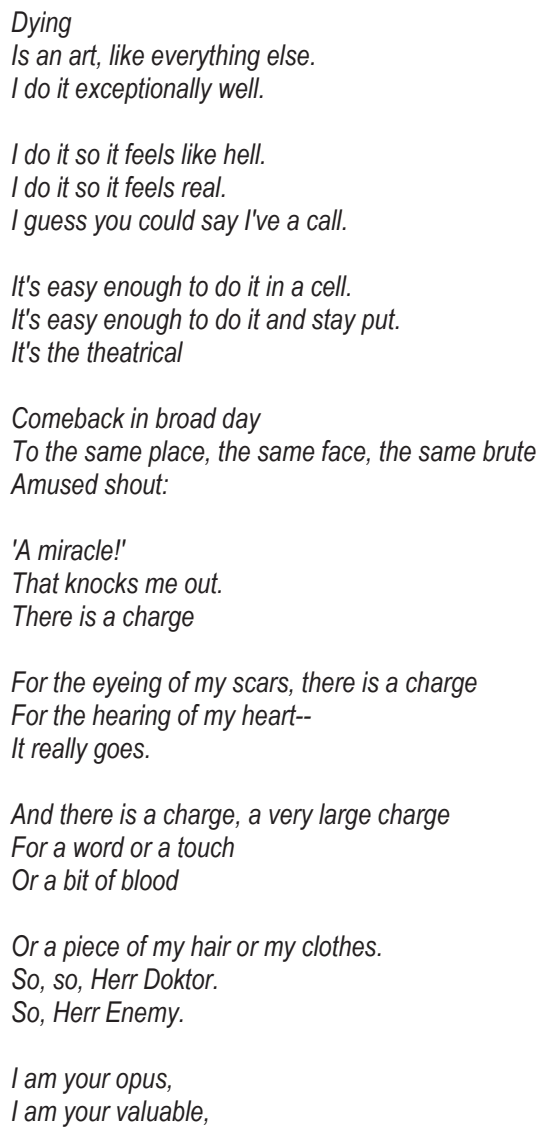


The pure gold baby

That melts to a shriek.

I turn and burn.

Do not think I underestimate your great concern.

\author{
Ash, ash-- \\ You poke and stir. \\ A cake of soap, \\ A wedding ring, \\ A gold filling. \\ Herr God, Herr Lucifer \\ Beware \\ Beware. \\ Out of the ash \\ I rise with my red hair \\ And I eat men like air.
}

Flesh, bone, there is nothing there--

\title{
23-29 October 1962
}

This "charge" is highly susceptible to an overdetermined, transferred interpretation. This English term can refer to either the cost of something or electric energy. At face value, the charge is something she wants the crowd to pay for seeing and hearing her pain and suffering, but given that it is her suffering, and her "knock out" that immediately precedes, it is difficult not to think that she is actually the one paying this charge. In fact, Plath's first recorded suicide attempt was both preceded and followed by subjection to electroshock therapy, so it is highly tempting to infer that this charge was the electric treatments that she was forced to undergo as treatment for her depression. Professor Shanhsiung Ting ${ }^{1}$ has further suggested that this charge may also refer to the doctor's bills which her family had to pay at the time, and which she probably resented. Thus, "charge" is overdetermined in the Freudian sense of having multiple possible interpretations, and reflects transference in how these different meanings adhere to different internal and external relations.

The poem culminates in an allusion to the phoenix, a bird which may be reborn from its own ashes, additionally symbolized by the author's red hair. This rebirth will further give the author the opportunity to overcome the forces that have tormented her: God, Lucifer, a "Dokter", an Enemy, all prefixed with the German masculine courtesy title "Herr". George Steiner comments that "committing the whole of her poetic and formal authority to the metaphor, to the mask of language, Sylvia Plath became a women being transported to Auschwitz on the death trains." Professor Van Dyne more generally argues that "the heroine's last gesture underscores the wish driving the entire poem, the wish to appropriate the powers that threaten to destroy her" and further "reverse the dominance she identifies with these male figures" (146). Appreciating the masculine aspect of these oppressive personages helps explain why the commentary on Sylvia Plath in Literature Annotations suggests that "Lady Lazarus" may 'provide insight into the frame of mind of a conflicted, talented woman attempting to make her mark during the period before "women's lib"'. While "your valuable, The pure gold baby" probably can be read with a sarcastic voice railing against such objectification, "your opus" has an epic tone that is less easily dismissed. In fact, in her poem "Daddy", written during the exact same period in the fall of 1962, Plath wrote "I thought every German was you". In explicit Freudian allusion, the second stanza of the poem starts, "Daddy, I have had to kill you. You died before I had time--". While Plath's role as a feminist icon is socially and historically significant and has inspired important analysis of her work, from the Freudian perspective adopted here, these personages must be understood as simultaneously her father and her death wish. Freud's work suggests that many of us are subject to this conflation, and Plath's life experience particular reinforced it.

Plath identifies global political metaphors with her own personal suffering in other poems as well. "Fever 103" harnesses the terror of nuclear catastrophe while simultaneously alluding to her husband's infidelity, her miscarriage,

1 This interesting idea was suggested by Professor Ting during the comment period after our presentation at Hwa Kang Conference on English Language and Literature in 2011. 
and/or her pregnancies.

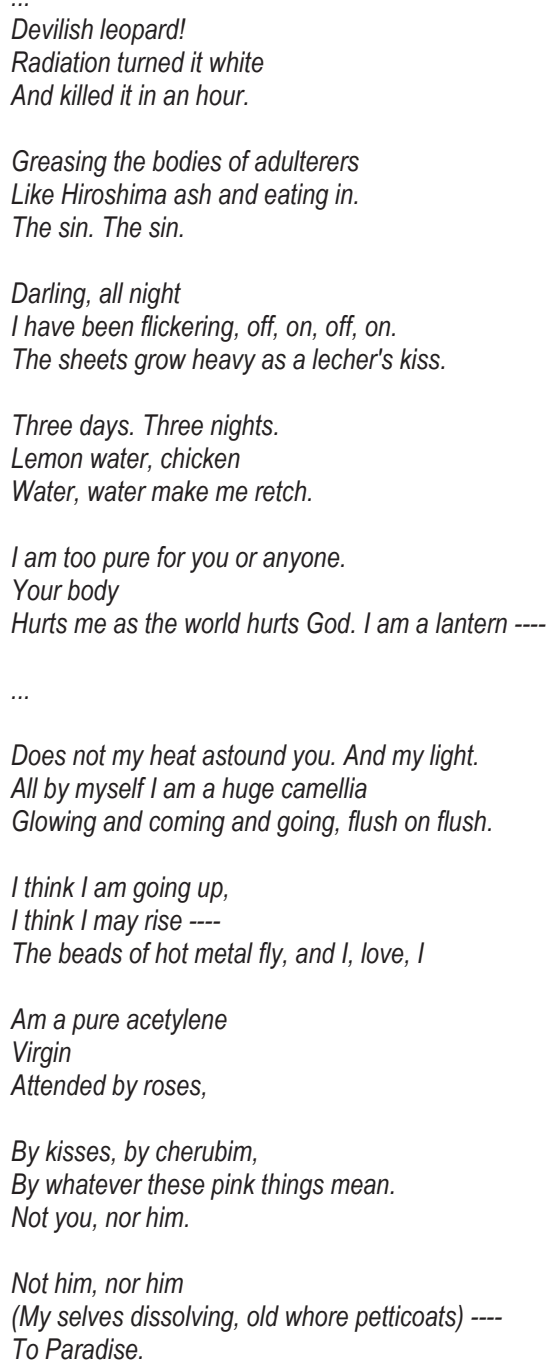

References to radiation and Hiroshima establish the context of nuclear horror, while references to adulterers and a lecher suggest her disgust with her husband, having discovered his infidelity in the months preceding the composition of this poem. Oddly, the stanza which speaks to her "Darling" and describes herself as flickering on and off seems out of keeping with the purity that is a dominant theme of the rest of the poem. Thus, it is tempting to interpret this passage as identity transference of her husband's lover onto herself.

On the other hand, the retching which immediately follows may be seen as the outcome of sexual union, that is to say, pregnancy, insofar as 'morning sickness' is a common symptom among pregnant women. Taking this train of thought further, this purity may even be a reference to the miscarriage which Plath suffered in February 1961. She was able to give birth to her second child, a boy, in January 1962, and the poem was not composed until late 1962. Still, speaking of herself as a lantern, whose heat astounds, this radiation which kills may even be that of her own body rejecting her unborn child. These "him" that end the poem can also then be understood as her husband, her son, her unborn baby, and/or her father. Thus, this poem simultaneously expresses the feelings which inevitably transferred themselves between all these diverse relationships, and the symbols of the poem are overdetermined in the sense of simultaneously representing her feelings about all these relationships. 
This poem notably dichotomizes external violence and the author's purity while containing both positive and negative sexual imagery. We might speculate that projecting her own self-destructive tendencies onto the husband who injured her, actually freed her temporarily to embrace her own life forces. This poem also shows how writing gave Plath a means to struggle to overcome the torment and suffering that life had presented her with. Still, she is so pure that she cannot even keep down water, and ultimately still seeks her "selves dissolving".

Poems such as "Ariel" further reaffirm her identification with the urge to self-destruction, though it is the "dead stringencies" of life that her suicidal drive will remove.

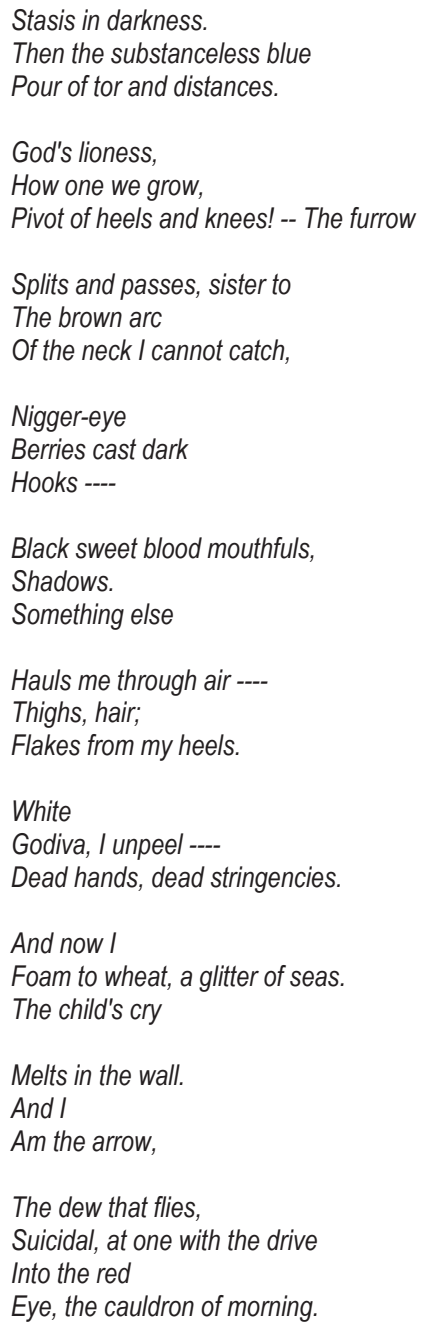

D.F. McKay notes that this poem can be read as "a poem about the experience of horseback riding at dawn" (18). Ariel is the name of the horse, but also what Isiah calls the city of Jerusalem (Isa. 29:7), meaning "Lion of God". McKay claims "here, the deity is an immanent and coercive animal power, remorselessly pulling the rider out of her sense of personal identity and into a unity with itself" (18). While this description is poetic and insightful, this paper has tried to argue that this suicidal drive was a very fundamental part of Plath's sense of personal identity. Freud's psychological analysis of the human psyche specifically charted how such dangerous forces may simultaneously be externalized and internalized. McKay even notes that the poem, from a psychological perspective, "expresses a conventional death wish, a desire for extinction" (18). Poignantly, she rides into a sunrise, rather than a sunset, which might more conventionally be associated with death. This twist evokes Freud's ideas of restoration and the return to earlier beginnings. 
A. Alvarez, who was a friend of Plath's and published a book on suicide, interpreted her suicide as "both a cry for help that misfired and a last desperate attempt to exorcise the death she had summoned up in her poems" (qtd. in Bassnet 24). Friends often have deeper insights into each other's conditions, but personal connections can also bias interpretations. It is a little difficult to understand how suicide could be described as 'exorcising death', but Ariel's unpeeling of the dead weights of life gives us some idea of how confounded life and death must have been for Plath. Again, Freudian interpretation provides multiple concepts for understanding and explaining this confounding of life and death.

Understanding self-destructive tendencies as futile attempts at restoration also implies the superficial irrelevance of pop culture inclinations to distinguish whether someone "meant to do it" or was just making "a cry for help". She spoke candidly of both the allure and frustration, the glamour and shame, of dying and living over and over again. Freud ultimately treated the death drive as a fundamental instinct, and in Plath's own words, she finally became "one with the drive".

However, poem's like "Elm" speak to the ambivalence that must have constantly haunted her, while reinforcing imagery of primordial peace and transference between internal and external relations.

\author{
I know the bottom, she says. I know it with my great tap root; \\ It is what you fear. \\ I do not fear it: I have been there. \\ Is it the sea you hear in me, \\ Its dissatisfactions? \\ Or the voice of nothing, that was you madness? \\ I am inhabited by a cry. \\ Nightly it flaps out \\ Looking, with its hooks, for something to love. \\ I am terrified by this dark thing \\ That sleeps in me; \\ All day I feel its soft, feathery turnings, its malignity.
}

Roots and seas evoke images of the original sources of life. This sea, this cry, this dark thing all seem to be external objects that have been internalized, and yet they may just as well be considered the externalized symbols of her own dark, frustrated, confused desires. If her death drive is both the root and the dark thing, then one voice claims no fear, while another clearly admits it. Presumably, "I have been there" refers to her previous unsuccessful attempts at suicide. What's more, this dark fearful thing is not just described for its repugnant "malignity", but also its alluring "soft, feathery turnings". Plath had every reason to be scared because the death drive was so strong in her, but Freud long ago argued that it's there in all of us, constantly tempting, both comforting and dangerous.

In short, Sylvia Plath's poems are full of numerous descriptions of her instinctive drive towards death. Plath's emotional struggles as reflected in her poems poignantly reveal the kind of battles which Freud described as the conflict between life and death instincts. This paper has shown how she frequently uses overdetermined symbols referencing internalized and externalized relations of transference which repeat past experiences in attempts at restoration. Though she attempted to transcend through sublimated writing the death drive that obsessed her, the overwhelming power of these instincts finally conquered her desire for life. However, her writing was able to sustain her for some time, and through this work, we also can peer into the magnetic attraction of these destructive forces.

\title{
References
}

Andersen, S. M. \& Berk., M. "The social-cognitive model of transference: Experiencing past relationships in the present." Current Directions in Psychological Science 7(4). 1998: 109-15. Print.

Bassnett, Susan. Sylvia Plath. London: Macmillan Education Ltd., 1987. Print.

Davison, Peter. "Inhabited by a Cry: The Last Poetry of Sylvia Plath" [Ariel] Critical Essays on Sylvia Plath. Ed. Linda W. Wagner. Boston: G. K. Hall \& Company, 1984. 38-41. Print

Freud, Sigmund. Beyond the Pleasure Principle. Trans. by C. J. M. Hubback. London, Vienna: International Psycho-Analytical, 1922. Print.

---. The Ego and the Id. London: The Hogarth Press Ltd. 1949. Print. 
---. The Freud Reader. Ed. By Peter Gay. NY: WW. Norton and Co.1995. Print.

---. The Interpretation of Dreams. Leipzig \& Vienna: Franz Deuticke, 1899. Print.

Literature Annotations. Literature, Arts and Medicine Database. 28 June 2004. <http://endeavor, med.nyu.edu/lit-med/lit-med$\mathrm{db} /$ webdocs/webdescrips/plath43-des-.html>

Lucas, Victoria. The Bell Jar. London: Heinemann, 1963. Print.

McKay, D. F. "Aspects of Energy in the Poetry of Dylan Thomas and Sylvia Plath."

Olsen, Ole Andkjaer and Koppe, Simo. Freud's Theory of Psychoanalysis. NY: New York UP, 1988. Print.

Runco, Mark A. "Suicide and Creativity: The Case of Sylvia Plath." A Death Studies 22 (Oct-Nov 1998): 637-55. Print.

Steiner, George. "Dying Is An Art." The Art of Sylvia Plath: A Symposium. Ed. Charles Newman. Bloomington: Indiana UP, 1970. Print.

Sylvia Plath. Ed. Harold Bloom. New York: Chelsea House Publishers, 1989. 17-32. Print.

Sylvia Plath. Introduction. Ariel. By Robert Lowell. New York: Harper \& Row, 1966. Print.

Van Dyne, Susan R. " 'More Terrible Than She Ever Was': The Manuscripts of Sylvia Plath's Bee Poems." Critical Essays on Sylvia Plath. Ed. Linda W.

Wagner. Boston: G. K. Hall \& Company, 1984. Print.

Wagner, L. W. Sylvia Plath: The Critical Heritage. Ed. Linda W. Wagner. New York: Routledge, Chapman and Hall Inc. 1988. Print.

A Wind of Such Violence. 5 May 2011. <http://www.angelfire.com/tn/plath/ariel.html>

A Wind of Such Violence. 2 May 2011. <http://angelfire.com/tn/plath/daddy.html>

A Wind of Such Violence. 5 May 2011. <http://www.angelfire.com/tn/plath.elm.html>

A Wind of Such Violence. 2 May 2011. <http://www.angelfire.com/tn/plath/lady.html>A Wind of Such Violence. 2 May 2011. http://angelfire.com/tn/plath/103.html 